\title{
Pheromonal bile acid 3-ketopetromyzonol sulfate primes the neuroendocrine system in sea lamprey
}

Yu-Wen Chung-Davidson ${ }^{1}$, Huiyong Wang ${ }^{1}$, Michael J Siefkes ${ }^{1,2}$, Mara B Bryan ${ }^{1,3}$, Hong Wu ${ }^{1,4}$, Nicholas S Johnson ${ }^{1,5}$ and Weiming $\mathrm{Li}^{\mathrm{i}^{*}}$

\begin{abstract}
Background: Vertebrate pheromones are known to prime the endocrine system, especially the hypothalamicpituitary-gonadal (HPG) axis. However, no known pheromone molecule has been shown to modulate directly the synthesis or release of gonadotropin releasing hormone $(\mathrm{GnRH})$, the main regulator of the HPG axis. We selected sea lamprey (Petromyzon marinus) as a model system to determine whether a single pheromone component alters the output of GnRH.

Sea lamprey male sex pheromones contain a main component, 7a, 12a, 24-trihydroxy-5a-cholan-3-one 24-sulfate (3 keto-petromyzonol sulfate or $3 \mathrm{kPZS}$ ), which has been shown to modulate behaviors of mature females. Through a series of experiments, we tested the hypothesis that $3 \mathrm{kPZS}$ modulates both synthesis and release of $\mathrm{GnRH}$, and subsequently, HPG output in immature sea lamprey.

Results: The results showed that natural male pheromone mixtures induced differential steroid responses but facilitated sexual maturation in both sexes of immature animals $\left(x^{2}=5.042, d F=1, p<0.05\right)$. Exposure to $3 \mathrm{kPZS}$ increased plasma 15a-hydroxyprogesterone $(15 a-P)$ concentrations (one-way ANOVA, $p<0.05)$ and brain gene expressions (genes examined: three lamprey (I) GnRH-I transcripts, IGnRH-III, Jun and Jun N-terminal kinase (JNK); one-way ANOVA, $p<0.05$ ), but did not alter the number of $\mathrm{GnRH}$ neurons in the hypothalamus in immature animals. In addition, 3kPZS treatments increased IGnRH peptide concentrations in the forebrain and modulated their levels in plasma. Overall, 3KPZS modulation of HPG axis is more pronounced in immature males than in females.
\end{abstract}

Conclusions: We conclude that a single male pheromone component primes the HPG axis in immature sea lamprey in a sexually dimorphic manner.

Keywords: Pheromone, Priming, HPG axis, GnRH, Steroid, Sexual dimorphism

\section{Background}

The term "pheromones" was first introduced by Karlson and Lüscher (1959) to describe the substances involved in chemical communication among conspecifics [1]. Pheromones can be classified as releasers, primers, or more recently, signalers and modulators [2-6]. These functions are not mutually exclusive. Primer pheromones are exemplified by their effects on the onset of puberty, the length of

\footnotetext{
* Correspondence: liweim@msu.edu

'Department of Fisheries and Wildlife, Michigan State University, 13 Natural Resources Building, 480 Wilson Road, East Lansing, MI 48824, USA Full list of author information is available at the end of the article
}

estrous cycles in females, the success or failure of pregnancy, and shifts in hormone levels in mice [6]. Male pheromones have a direct impact on female sexual desire, menstrual cycles and ovulation in humans [7]. About 20\% of women who have smelled male underarm secretions have an advanced onset of next luteinizing hormone (LH) pulse [8]. These primer pheromones are all putative pheromones since their chemical structures have yet to be determined.

Sex pheromones exert priming effects via the HPG axis that links environmental inputs to reproductive outputs [3]. Pheromone extracts or pheromone components have

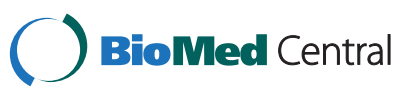


been shown to affect gonadotropin (GTH) or LH surge in many species $[6,9,10]$. However, no known pheromone component has been shown to directly induce $\mathrm{GnRH}$ release [9-12]. In fish, most studies of GnRH or GTH release have focused on seasonal changes and very few studies pay attention to the daily cycle or pulsatility of GnRH or GTH.

Sea lamprey provides an advantageous vertebrate model to examine the mechanisms by which a pheromone component primes the HPG axis since lamprey GnRH peptides are well characterized [13], and several pheromone molecules have been identified in this species [14-17]. Sea lamprey occupy a key position close to the root of the vertebrate phylogenetic tree $[18,19]$. They develop through three distinct life stages [20,21]. Larval sea lamprey spends several years in burrows as benthic filter feeders in the stream. After going through metamorphosis [22], the resulting parasitic juveniles enter large lakes or the ocean to feed on host fish. After 1.5 to 2 years, the adults cease feeding in the early spring and migrate into rivers to spawn and then die [20,21]. For parasitic sea lamprey, sexual maturation is halted until they cease feeding and begin an upstream spawning migration [23]. It is not clear how lGnRH-I and -III regulate the final maturation and whether there is a differential expression of hormones or prehormones during this stage. Males arrive at the spawning ground first, build a nest, and complete the final sexual maturation. Mature males release sex pheromones containing $3 \mathrm{kPZS}$ through the gills at the onset of spermiation [24]. It is known that $3 \mathrm{kPZS}$ stimulates olfactory receptor neurons in the olfactory epithelium [25], and induces upstream movement and searching behavior toward the nest in ovulatory females [14,26-28]. Downstream from the nests, immature animals are also exposed to $3 \mathrm{kPZS}$, the possible effects of which have not been examined.

We hypothesized that $3 \mathrm{kPZS}$ exerts priming effects by altering the HPG output in immature sea lamprey. To test this hypothesis, we first examined the effect of natural pheromone mixtures on sexual maturation of immature lamprey. We then examined the dose response and the time course of synthesized 3kPZS on plasma $15 \alpha-P$ concentrations, brain gene expressions of neuronal activation markers (Jun and JNK) and lGnRH-I and -III, and $\mathrm{GGnRH}$ peptide concentrations in the forebrain, hindbrain, and plasma. The results confirmed that waterborne $3 \mathrm{kPZS}$ modulated the synthesis and release of lGnRH-I and -III in immature sea lamprey.

\section{Results}

\section{Natural male pheromone mixtures facilitate sexual} maturation

Exposure to spermiating male washings (SMW, natural male pheromone mixtures) facilitated reproductive maturation in immature males and females $\left(\chi^{2}=5.042\right.$, $\mathrm{dF}=1, \mathrm{p}<0.05$; Table 1). On average, immature females exposed to SMW began to ovulate in 21 days, whereas immature females exposed to prespermiating male washings (PSMW, no pheromone control) did not start to ovulate until day 40 . For immature males, the average time to spermiate when exposed to SMW was 17 days; in contrast, when exposed to PSMW, none of the immature males produced milt by day 40 . Immature male lamprey appeared to mature faster $(17 \pm 3$ days $)$ than immature females ( $21 \pm 8$ days) after SMW exposure.

\section{Sex difference in steroid responses to natural male pheromone mixtures}

SMW exposure for $24 \mathrm{~h}$ altered plasma $15 \alpha-\mathrm{P}$ concentrations in immature sea lamprey (one-way ANOVA, $\mathrm{p}<0.05$; Figure 1). There were seasonal effects and sex differences in plasma $15 \alpha-P$ concentrations after exposure to SMW. Plasma 15 $\alpha-\mathrm{P}$ concentrations increased in immature males but decreased or showed no effect in immature females (Figure 1). Immature males showed an increase in $15 \alpha-\mathrm{P}$ concentrations in response to SMW exposure early in the spawning season (May and June) while immature females did not show the decrease in response to SMW until mid-season (June) and the response dropped abruptly after July (Figure 1).

\section{Exposure to $3 \mathrm{kPZS}$ increased plasma $15 a-\mathrm{P}$ in males}

Immature males showed elevated plasma $15 \alpha-P$ concentrations after continuous exposure to a wide range of $3 \mathrm{kPZS}$ for $4 \mathrm{~h}$ up to $8 \mathrm{~h}$ (2- to 4 -fold increase, Figure 2). Exposure to $10^{-10} \mathrm{M} 3 \mathrm{kPZS}$ for $4 \mathrm{~h}$ was the most effective treatment to increase plasma $15 \alpha-\mathrm{P}$ concentration (4-fold change, Figure 1). $3 \mathrm{kPZS}$ had no effect on plasma $15 \alpha-\mathrm{P}$ concentrations in immature females (Figure 2). There was no apparent dose effect of $3 \mathrm{kPZS}$ within the range examined. In fact, higher concentration $\left(10^{-9} \mathrm{M}\right)$ of $3 \mathrm{kPZS}$ appeared to show longer latency in elevating plasma $15 \alpha-\mathrm{P}$ compared to lower concentration $\left(10^{-11} \mathrm{M}\right.$ or $10^{-10} \mathrm{M}$, Figure 2).

\section{Induction of forebrain gene expression after $3 \mathrm{kPZS}$ exposure in males}

$3 \mathrm{kPZS}$ was most effective at $10^{-11} \mathrm{M}$ with $24 \mathrm{~h}$ exposure time, inducing 7 - to 21 -fold increase in forebrain gene expressions. As the concentration of $3 \mathrm{kPZS}$ increased, the peak of gene expressions shifted to earlier time points (Figure 3) but the magnitude decreased.

Exposure to $10^{-11} \mathrm{M}$ 3kPZS increased all mRNA transcripts examined in the forebrain of immature males (Figure 3). All three known splice variants of IGnRH-I mRNA were altered by 3kPZS exposure. GAP49 transcripts increased after exposure for $8 \mathrm{~h}$ (4-fold), $24 \mathrm{~h}$ (8-fold), and $48 \mathrm{~h}$ (4-fold). Increases in GAP58 transcripts occurred 
Table 1 Natural pheromones facilitate sexual maturation

\begin{tabular}{ccccc}
\hline Treatment & Animals & Days to mature (Mean \pm S.E.M) & Percentage of maturation & No. of animals (Immature/Mature) \\
\hline PSMW & POF & 40 & 16.7 & $5 / 1$ \\
PSMW & PSM & ND & 0 & $6 / 0$ \\
SMW & POF & $21 \pm 8$ & 50 & $3 / 3$ \\
SMW & PSM & $17 \pm 3$ & 50 & $3 / 3$ \\
\hline
\end{tabular}

Exposure to water conditioned by mature male sea lampreys (spermiating male washings, SMW) facilitated reproductive maturation in immature males and females. On average, immature females (POF) exposed to SMW began to ovulate in 21 days, whereas POF exposed to immature male washings (PSMW) did not ovulate until day 40. For immature males (PSM), the average time to spermiate after exposure to SMW was 17 days; in contrast, when exposed to PSMW, none of the PSMs had spermiated by day $40 . \mathrm{X}^{2}=5.042, \mathrm{dF}=1, \mathrm{p}<0.05$ (Combine POF and PSM). ND: Not determined.

earlier and lasted longer after exposure for $4 \mathrm{~h}$ (4-fold), $8 \mathrm{~h}$ (4-fold), $24 \mathrm{~h}$ (13-fold), and $48 \mathrm{~h}$ (5-fold). GAP50 transcripts only increased after $24 \mathrm{~h}$ exposure (21-fold). lGnRH-III transcripts increased after exposure for $24 \mathrm{~h}$ (7-fold) and $48 \mathrm{~h}$ (5-fold). Jun transcripts increased after exposure for $8 \mathrm{~h}$ (5-fold), $24 \mathrm{~h}$ (14-fold), and $48 \mathrm{~h}$ (7-fold). $J N K$ transcripts increased after exposure for $8 \mathrm{~h}$ (2-fold) and $24 \mathrm{~h}$ (3-fold).

Exposure to $10^{-10} \mathrm{M} 3 \mathrm{kPZS}$ also increased all mRNA transcripts examined in the forebrain of immature males (Figure 3). GAP49 transcripts increased after exposure for $4 \mathrm{~h}$ (2-fold), $8 \mathrm{~h}$ (4-fold), and $24 \mathrm{~h}$ (3-fold). GAP58 transcripts increased after exposure for $8 \mathrm{~h}$ (3-fold) and $24 \mathrm{~h}$ (2-fold). GAP50 transcripts only increased after exposure for $8 \mathrm{~h}$ (5-fold). lGnRH-III transcripts increased after exposure for $8 \mathrm{~h}$ (3-fold), $24 \mathrm{~h}$ (3-fold), and $48 \mathrm{~h}$ (2-fold). Jun transcripts increased the earliest, after exposure for $2 \mathrm{~h}$ (2-fold), $8 \mathrm{~h}$ (3-fold), and $24 \mathrm{~h}$ (3-fold). JNK transcripts increased after exposure for $8 \mathrm{~h}$ (2-fold) and $24 \mathrm{~h}$ (2-fold).

Exposure to $10^{-9} \mathrm{M}$ 3kPZS only increased lGnRH-I transcript variants, IGnRH-III and Jun mRNA concentrations in the forebrain of immature males (Figure 3). GAP49 transcripts increased after exposure for $4 \mathrm{~h}$ (2-fold), $8 \mathrm{~h}$ (4-fold), and $24 \mathrm{~h}$ (3-fold). GAP58 transcripts increased later after exposure for $8 \mathrm{~h}$ (3-fold) and $24 \mathrm{~h}$ (2-fold). GAP50 transcripts only increased after $8 \mathrm{~h}$ exposure (5-fold). lGnRH-III transcripts increased after exposure for $8 \mathrm{~h}$ (3-fold), $24 \mathrm{~h}$ (3-fold), and $48 \mathrm{~h}$ (2-fold). Jun transcripts rose the earliest, after exposure for $2 \mathrm{~h}$ ( 2 -fold), $8 \mathrm{~h}$ (3-fold), and $24 \mathrm{~h}$ (3-fold).

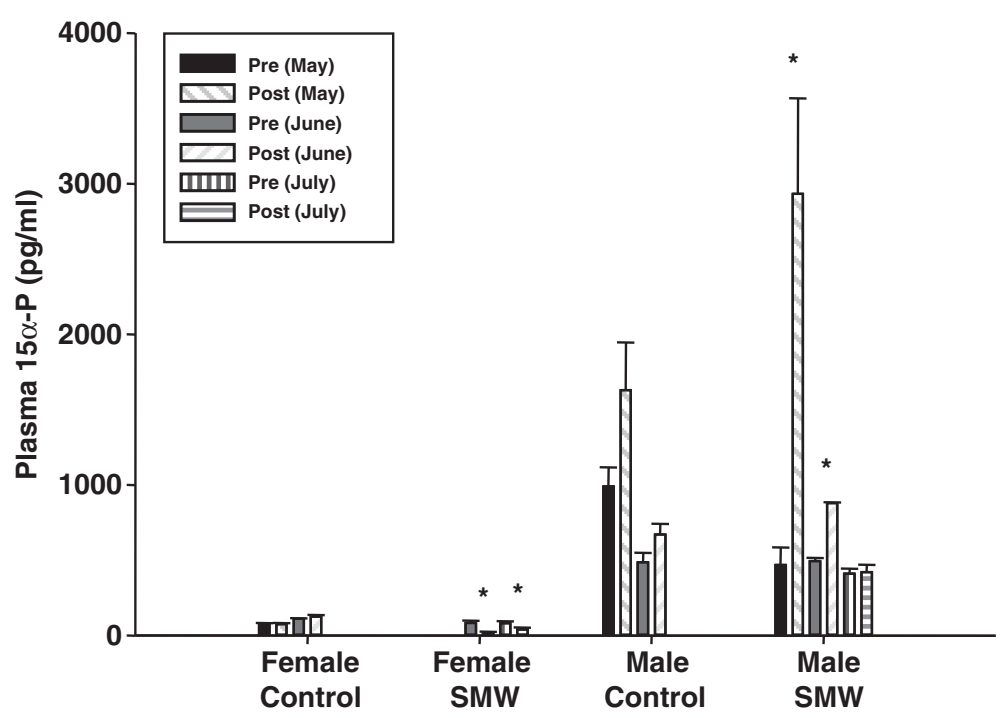

Figure 1 Sex difference in seasonal steroidal responses after natural pheromone exposure in sea lamprey. Exposure to mature male washings (SMW) for $24 \mathrm{~h}$ decreased plasma 15a-hydroxyprogesterone (15a-P) concentrations in immature females in June and July while the same treatment increased 15a-P concentrations in immature males in May and June. Lake Huron water (control) and immature male washings (data not shown) had no effect on 15a-P levels in either sex. Females did not have detectable 15a-P in their plasma early in the spawning season (May), but as the season progressed in June and July, plasma 15a-P concentrations became detectable. In immature males, changes in circulating 15a-P after SMW treatment was greater earlier in the spawning season (May) but diminished in later in the season (July). Sex differences in plasma 15a-P concentrations were significant $(p<0.05)$. * Statistically significant between pre- and post-treatment level in the same group $(p<0.05)$. 

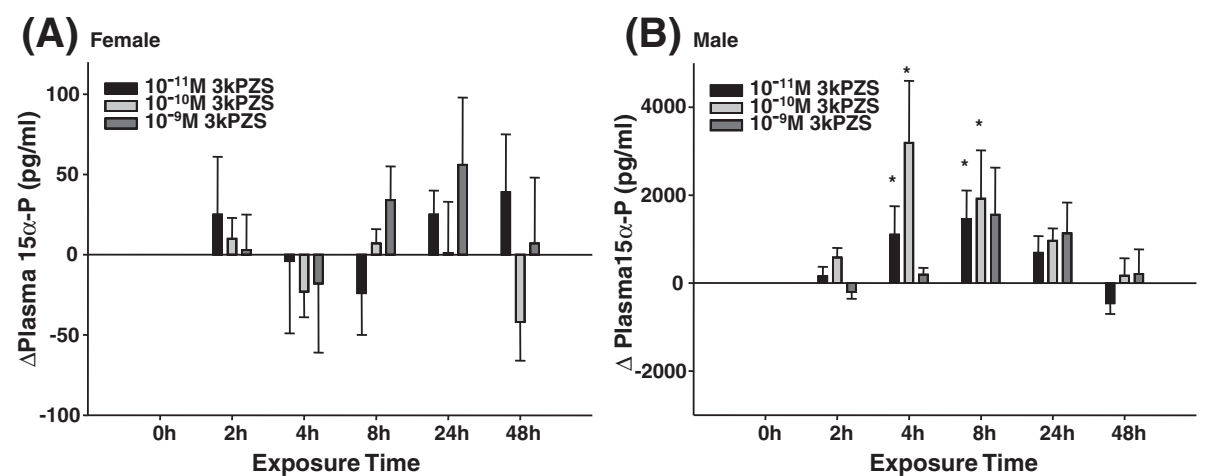

Figure 2 Sex difference in steroidal responses after exposure to synthesized pheromone component in sea lamprey. Exposure to $3 \mathrm{kPZS}$ increased plasma 15a-hydroxyprogesterone (15a-P) concentrations in immature male but not in immature female sea lamprey. $\Delta 15 \mathrm{a}-\mathrm{P}=$ (post-treatment 15a-P level) - (pre-treatment 15a-P level). * Statistically different from $0 \mathrm{~h}$ control group $(\mathrm{p}<0.05)$.

Sex difference in forebrain gene expression after $3 \mathrm{kPZS}$ exposure

Immature females showed increases in Jun (2-fold) and JNK (2-fold) expression rapidly $(2 \mathrm{~h})$ after $10^{-11} \mathrm{M}$ 3kPZS exposure (Figure 3), whereas immature males had more delayed responses ( $\geq 4 \mathrm{~h}$, Figure 3 ). Exposure to $10^{-10} \mathrm{M}$ or $10^{-9} \mathrm{M} 3 \mathrm{kPZS}$ had no effect on forebrain gene expression in immature females (Figure 3).

\section{Differential effect of $3 \mathrm{kPZS}$ on hindbrain gene expression}

In the brain stem of immature males, $3 \mathrm{kPZS}$ seemed to be most effective at $10^{-10} \mathrm{M}$ in increasing gene expressions, and the response appeared to be phasic with an earlier peak $(2 \mathrm{~h})$ and a delayed peak $(48 \mathrm{~h})$ at the time points examined. On the other hand, in the brain stem of immature females, only $10^{-10} \mathrm{M} 3 \mathrm{kPZS}$ decreased GAP50 expression after $2 \mathrm{~h}$ (2-fold), $8 \mathrm{~h}$ (3-fold) and $48 \mathrm{~h}$ (2-fold) exposure (Figure 4). 3kPZS at other concentrations examined showed no effect on hindbrain gene expression in immature females (Figure 4).

The brain stem of immature males showed more pronounced gene expression changes than the forebrain after exposure to $10^{-11} \mathrm{M} 3 \mathrm{kPZS}$. 1GnRH-III transcripts increased after $2 \mathrm{~h}$ (19-fold) and $48 \mathrm{~h}$ (55-fold) exposure (Figure 4). Jun transcripts increased after $48 \mathrm{~h}$ exposure (99-fold, Figure 4). JNK transcripts increased after $2 \mathrm{~h}$ (2-fold), 8 h (2-fold), $24 \mathrm{~h}$ (2-fold), and $48 \mathrm{~h}$ (4-fold) exposure (Figure 4).

At $10^{-10} \mathrm{M} 3 \mathrm{kPZS}$ increased GAP49 transcripts after $8 \mathrm{~h}$ exposure (2-fold). Jun transcripts increased after $2 \mathrm{~h}$ (9-fold) and $48 \mathrm{~h}$ (8-fold) exposure. Prolonged exposure to $10^{-10} \mathrm{M} 3 \mathrm{kPZS}$ (48 h) increased GAP58 (1122-fold), lGnRH-III (826-fold), and JNK (2-fold) transcripts in the brain stem of immature males (Figure 4).

At $10^{-9} \mathrm{M} 3 \mathrm{kPZS}$ increased 1 GnRH-III transcripts after $8 \mathrm{~h}$ (379-fold) and $48 \mathrm{~h}$ (1052-fold) exposure (Figure 4). Jun transcripts increased after exposure for $2 \mathrm{~h}$ (12-fold) and $48 \mathrm{~h}$ (16-fold, Figure 4). JNK transcripts increased after exposure for $2 \mathrm{~h}$ (2-fold), $4 \mathrm{~h}$ (2-fold), $8 \mathrm{~h}$ (2-fold), and $48 \mathrm{~h}$ (2-fold, Figure 4). Prolonged exposure to $10^{-9} \mathrm{M}$ 3kPZS (48 h) decreased GAP49 (7-fold) but increased GAP58 (2735-fold) expressions in the brain stem of immature males (Figure 4).

\section{Differential effect of 3kPZS on forebrain and plasma IGnRH peptide concentrations}

Exposure to $10^{-10} \mathrm{M} 3 \mathrm{kPZS}$ increased lGnRH-I and -III peptide concentrations in the forebrain (Figures 5 \& 6) but had no effect in the brain stem of immature males (Additional file 1: Figures S1\& S2). Plasma 1GnRH-I and -III peptide concentrations pulsed at the short time course after $3 \mathrm{kPZS}$ exposure. $3 \mathrm{kPZS}$ increased plasma IGnRH-I and -III peptide concentrations when the control level was low, but this effect was inhibited when the control level was high (Figures 5 \& 6).

\section{No effect of $3 \mathrm{kPZS}$ on the number of IGnRH neurons in the hypothalamus}

The distribution of IGnRH mRNA, observed in the in situ hybridization experiments, was similar to that observed by Reed et al. [29], and was found mainly in the preoptic-hypothalamic area (Additional file 1: Figure S3). Immunocytochemistry using antibodies specific for lGnRH-I and -III demonstrated that the distributions of lGnRH-I or lGnRH-III immunoreactivities in lamprey brain (Additional file 1: Figures S4 \& S5) were consistent with data described by Nozaki et al. [30]. Exposure to $3 \mathrm{kPZS}$ had no effect on the number of IGnRH-I or -III immunoreactive cells in the preoptic-hypothalamic area.

\section{Discussion}

To our knowledge, this is the first study of the dose response and time course of the priming effects of a single pheromone component on GnRH synthesis and release. The synthesized male pheromone molecule affects both sexes but induces more dramatic responses in males. An 


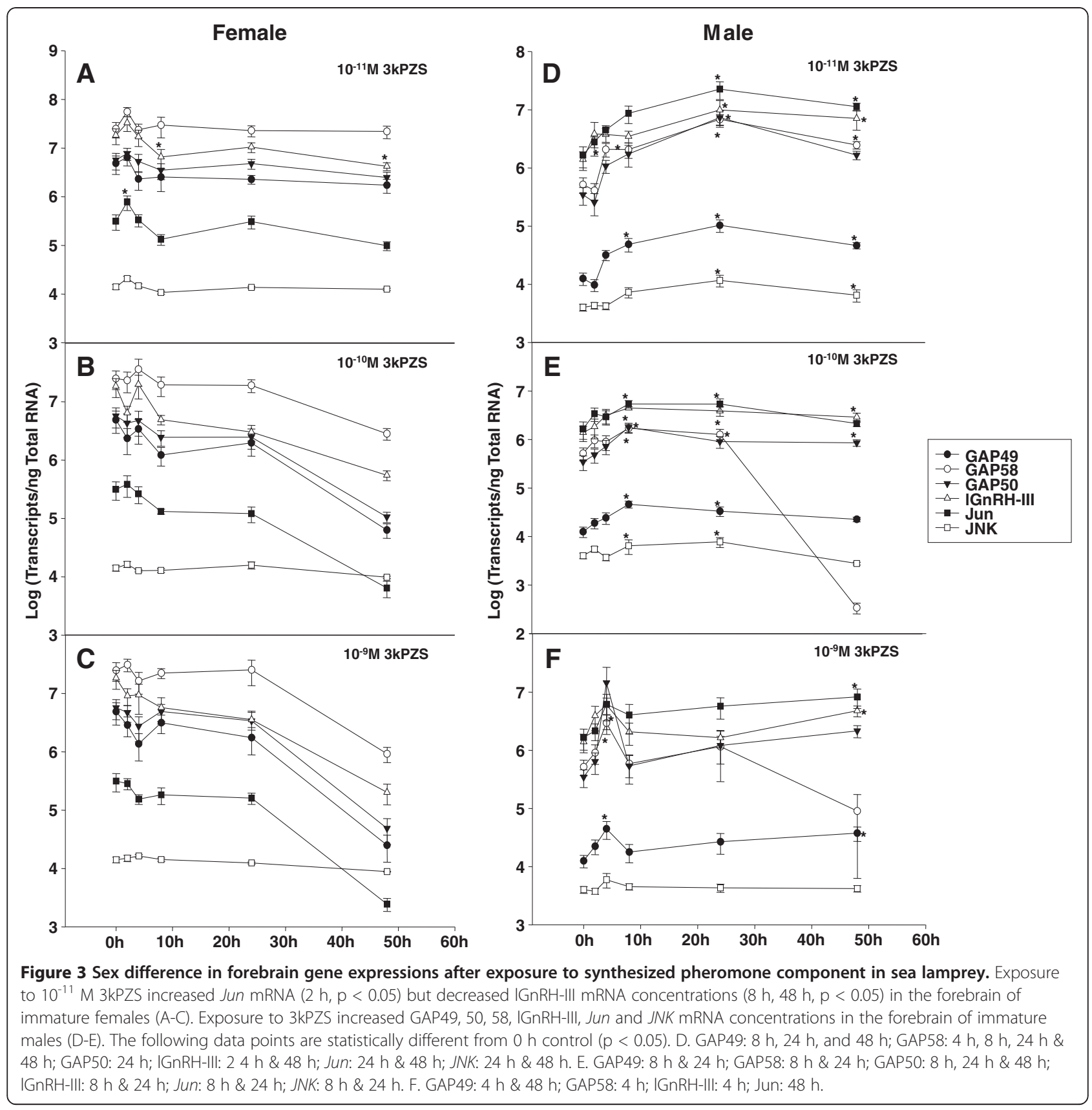

interesting possibility is that immature males develop the ability to respond to $3 \mathrm{kPZS}$ as a result of chemical spying [31] since odors from conspecifics of the same sex tend to diminish reproductive activities in most species and there is no benefit to the mature males in broadcasting a signal to immature males [32]. As migratory adults arrive at the spawning ground with various sexual maturity at different times throughout the spawning season (about 2-3 months), spying on sex pheromones to synchronize gonadal development and other aspects of spawning readiness would be beneficial because sea lamprey are semelparous, i.e., spawning only once in their life time. This is especially important for immature males since they have to build nests and accelerate final sexual maturation so that they can release sex pheromones to attract mature females. The sex difference in the response to $3 \mathrm{kPZS}$ also revealed that different genders are likely tuned in to different chemical signals.

Waterborne $3 \mathrm{kPZS}$ increased forebrain $\mathrm{GGnRH}$ peptide concentrations and gene expressions, and altered plasma lGnRH peptide and sex steroid concentrations. These results indicate that 3kPZS modulates $\mathrm{GnRH}$ release, which is important for steroidogenesis and final sexual maturation. Mammalian neurosecretory cells in the 


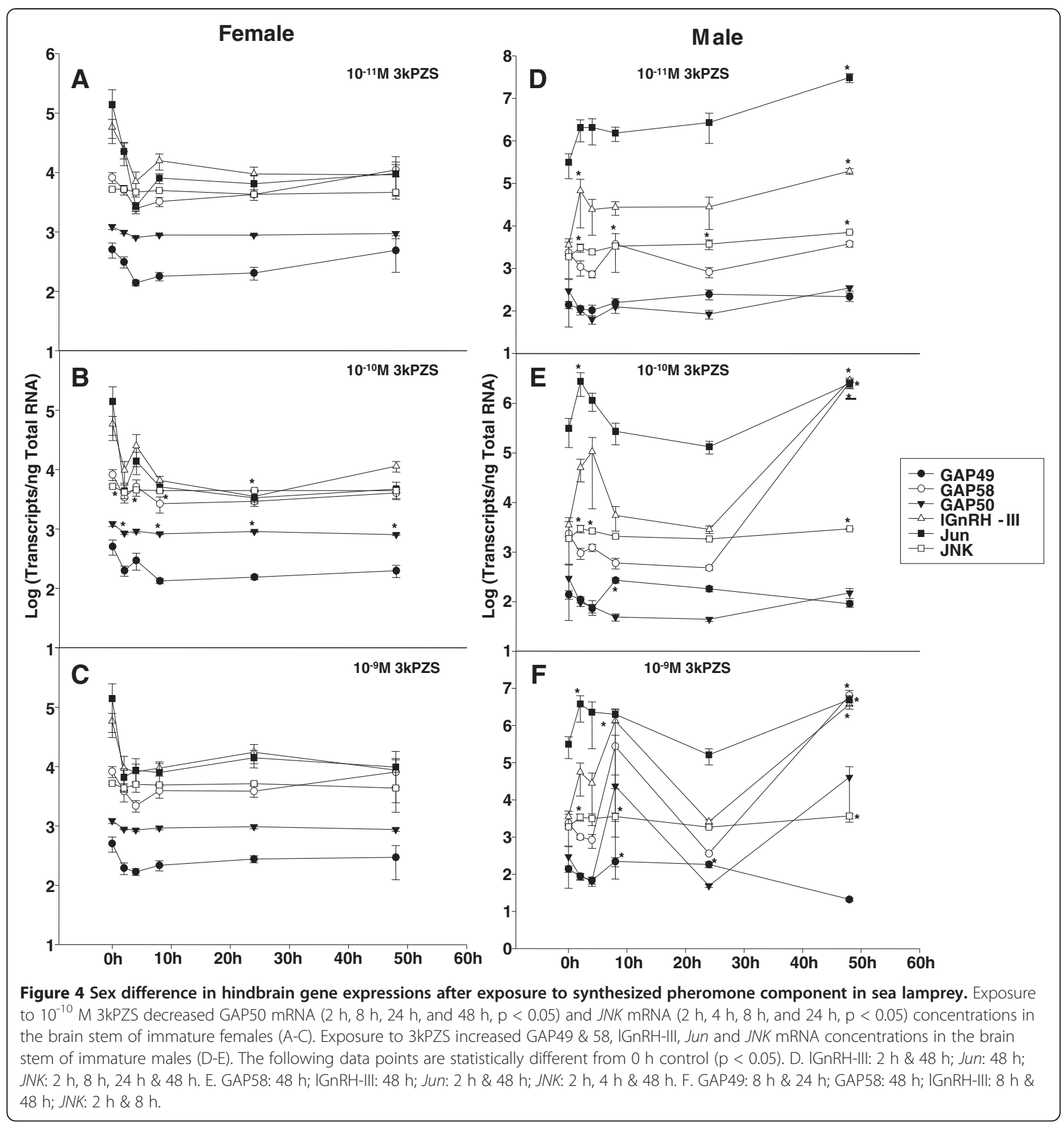

hypothalamus display pulsatile activities [33], and ovulation is induced by a LH (one of the mammalian counterparts of GTH) surge which is preceded by a surge of GnRH [LH releasing hormone (LHRH) in mammals] secretion into the brain portal system [34-36]. Parallel to this preovulatory increase in GnRH secretion is an increase in GnRH gene expression, as indicated by expression of the immediate-early genes (c-fos and c-jun) [37,38] and elevated GnRH mRNA [39,40], and increased levels of newly synthesized GnRH [41]. Lampreys and teleost fishes, however, lack the portal system in the brain, and GnRH neurons either terminate directly in the pituitary gland or release $\mathrm{GnRH}$ directly into the third ventricle $[42,43]$. Teleost fishes have well-characterized GTH with similar function and regulatory mechanisms as its mammalian counterpart [LH and follicle-stimulating hormone (FSH)]. A cDNA encoding lamprey GTH subunit $\beta$ has been cloned, but its function has not been validated [44].

We found differential expression of IGnRH-I and -III transcripts in sea lamprey brain exposed to $3 \mathrm{kPZS}$. 


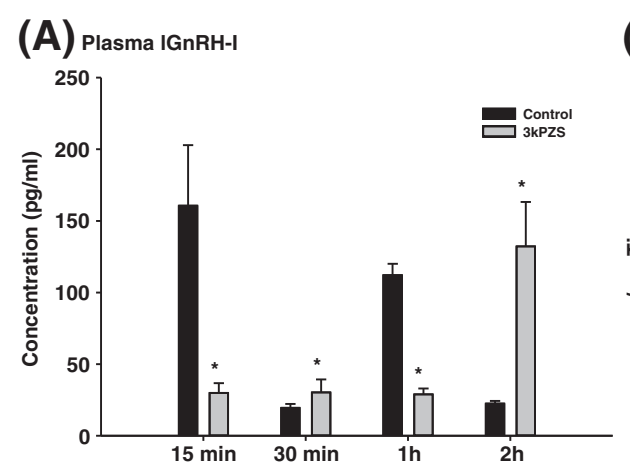

(B) Forebrain IGnRH-I

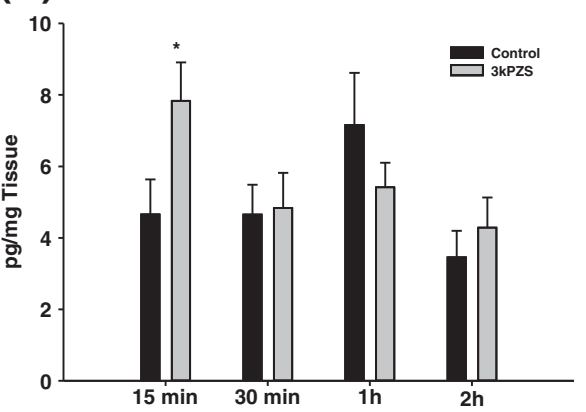

Figure 5 Differential effects of synthesized pheromone component on plasma and forebrain IGnRH-I concentrations in male sea lamprey. (A) Plasma IGnRH-I concentrations showed various effects after $10^{-10} \mathrm{M} 3 \mathrm{kPZS}$ exposure. Exposure to $10^{-10} \mathrm{M} 3 \mathrm{kPZS}$ increased IGnRH-I concentrations in the forebrain (B) but had no effect in the brain stem (data not shown).

Lampreys are the most primitive vertebrates for which multiple GnRH neurohormones are involved in pituitaryreproductive activity [45,46]. Both lGnRH-I and -III have been shown to induce gonadal maturation, steroidogenesis, and spermiation or ovulation in adult sea lamprey [45-49]. In immunocytochemical studies, both immunoreactiveIGnRH-I and -III can be found in the cell bodies of the rostral hypothalamus and preoptic area in larval and adult sea lamprey [30,44,50,51]. IGnRH-III was considered the more active form during development and gonadal maturation [52]. Our results indicated that $\mathrm{G}$ RRH-III concentrations were more responsive to pheromone exposure. However, IGnRH-I may be more important in inducing behavioral responses in mature females, given that the transcripts of its three splice variants fluctuated in the brainstem after pheromone exposure while lGnRH-III transcripts stayed constant.

It is interesting that three $\mathrm{lGnRH}-\mathrm{I}$ splice variants also showed differential expressions after pheromone exposure. Lamprey GnRH-I precursor was the first identified agnathan $\mathrm{GnRH}$ to contain the same tripartite structure with the signal peptide, GnRH decapeptide, and GnRH- associated peptide (GAP) as gnathostome $\mathrm{GnRH}$ precursors [52]. Unlike other known vertebrate $\mathrm{GnRH}$ precursors, which typically have one or two splice variants, three distinct splice variants were isolated and sequenced in lampreys [52]. The lGnRH-I splice variants, GAP49, GAP50 and GAP58, differed in the length of the GAP coding sequence [52]. The relative abundance of these splice variants in our results followed a magnitude decrease in the order of GAP58, GAP50, and GAP49. According to the changes after pheromone exposure, GAP50 seemed to be important for forebrain function whereas GAP49 and 58 may be associated with brainstem function in both sexes. However, forebrain GAP49 and brainstem GAP50 may serve additional functions in immature females [53].

Corresponding to its gene expression level in male sea lamprey, IGnRH-III is the most prominent lGnRH peptides in the brain and plasma. Its concentration is around 20 times more than IGnRH-I. We also found that 3kPZS altered the pulsatile pattern of $\mathrm{GnRH}$ concentrations in plasma. Pulsatile release of GnRH is a common neurobiological feature in vertebrates. It is autonomous within the GnRH neuronal network without
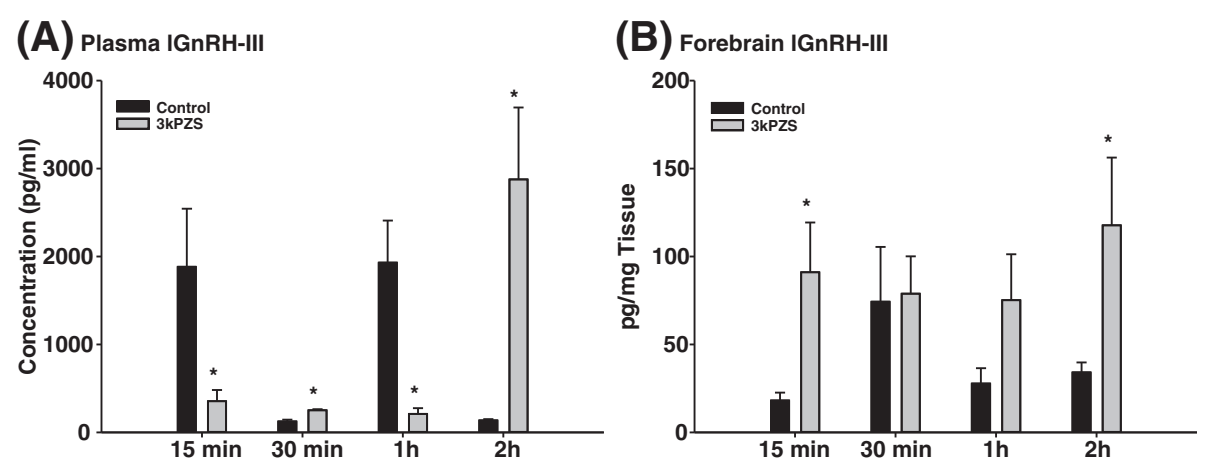

Figure 6 Differential effects of synthesized pheromone component on plasma and forebrain IGnRH-III concentrations in male sea lamprey. (A) Plasma IGnRH-III concentrations showed various effects after $10^{-10} \mathrm{M} 3 \mathrm{kPZS}$ exposure. Exposure to $10^{-10} \mathrm{M} 3 \mathrm{kPZS}$ increased IGnRH-III concentrations in the forebrain (B) but had no effect in the brain stem (data not shown). 
spontaneous pacemaker cells [54]. It is interesting that menstrual synchrony in humans is mediated by pheromones through two opposing effects of the same compounds [55]. Axillary compounds (putative human pheromones) from donor women in the follicular phase shortened both the time to ovulation and the length of the menstrual cycle in recipients and those in the ovulatory phase delayed ovulation and lengthened the total cycle [55]. We found that when GnRH level is low in the control group, 3kPZS increased GnRH peptide concentrations in the plasma whereas when $\mathrm{GnRH}$ level is high in the control group, 3kPZS showed opposite effects. There may be some similarity in the control mechanism involved in this process.

Pulsatile GnRH regulates the gonadotropin subunit genes in a differential manner, with faster frequencies (8 to 60 min pulse intervals) favoring mammalian LH $\beta$ subunit gene expression and slower frequencies $(\geq 120 \mathrm{~min}$ pulse intervals) favoring the expression of FSH $\beta$ subunit [56]. The mechanism is through the activation of GnRH receptor and its signaling cascades including JNK and its substrate JUN [57-61]. We found that 3kPZS induced GnRH release within $15 \mathrm{~min}$, and Jun and JNK gene expression after $2 \mathrm{~h}$ exposure, suggesting that $3 \mathrm{kPZS}$ can modulate $\mathrm{GnRH}$ release and its signaling cascades.

The detection of $1 \mathrm{GnRH}$ peptides in the plasma was a surprise since many previous attempts using HPLC and radioimmunoassays had failed to detect $\mathrm{G} n \mathrm{GH}$ peptides in sea lamprey plasma [62-65]. However, high-affinity binding sites for lGnRH peptides were detected in lamprey gonads, and GnRH appears to stimulate steroidogenesis independent of the pituitary $[48,66]$. Previous reports also noticed that the concentrations of brain $\mathrm{GnRH}$ peptides in lamprey occur at higher concentrations than seen in other vertebrates [62,67], suggesting that there may be a higher production or metabolism (or both) of each of the lGnRH peptides compared to gnathostomes [65]. Taken together, lGnRH peptides likely serve as hormones that are released into the third ventricle and then into the blood stream, and act on target organ such as gonads. Therefore, our results provide an additional explanation for GnRH binding affinity in peripheral organs [66]. Furthermore, our results support a possible peripheral endocrine function of $\mathrm{G} n R H$ peptides, which may bypass the pituitary gland in the HPG axis.

The acquisition of a HPG axis was a seminal event in vertebrate evolution leading to the neuroendocrine control of many biological functions [68]. GnRH is a critical neuropeptide that acts through the HPG axis to regulate vertebrate reproduction. However, invertebrate GnRH peptides seem to exert a wide range of central and peripheral functions not limited to reproduction [69]. In addition, $\mathrm{GnRH}$ may even function as spawning pheromone in invertebrates [70]. The presence of $1 \mathrm{GnRH}$ peptides in sea lamprey plasma indicates that the function of $\mathrm{lGnRH}$ peptides may not be fully centralized. It is likely that sea lamprey $\mathrm{GnRH}$ peptides function in an evolutionary transitional state where they not only act on the HPG axis, but also exert hormonal functions through systemic circulation. Furthermore, environmental factors such as a single pheromone component (i.e. 3kPZS) can modulate the HPG axis through olfaction. The considerable specialization of $\mathrm{GnRH}$ in the HPG axis as a reproductive activator may be a phenomenon specific to jawed vertebrates (gnathostomes) (Figure 7).

\section{Conclusions}

$3 \mathrm{kZPS}$ is a primer pheromone in sea lamprey that exerts its functions through the HPG axis via GnRH release.

\section{Methods}

\section{Animals}

Sea lamprey were collected by agents of the US Fish and Wildlife Service Marquette Biological Station (Marquette, MI) and Department of Fisheries and Oceans Canada Sea Lamprey Control Centre (Sault Ste. Marie, ON). Pheromone treatments of animals were conducted at the US Geological Survey Great Lakes Science Center Hammond Bay Biological Station (Millersburg, MI). For each set of experiments, all test subjects were captured from the same stream on the same day to reduce variation in maturity. Standard operating procedures for transporting, maintaining, handling, anesthetizing, and euthanizing sea lamprey were approved by the Institutional Committee on Animal Use and Care of Michigan State University (AUF\#05/09-088-00). Ethical guidelines were followed throughout the course of this research. Pheromone exposure time in the following experiments was chosen according to our previous publications $[14,53,71,72]$.

\section{Pheromone exposure experiment 1}

Twelve immature males were held in separate tanks (100 gallon; $16^{\circ} \mathrm{C}$; water replenishment $1 \mathrm{~L} \mathrm{~min}^{-1}$ ), and acclimated for 2 days. $16^{\circ} \mathrm{C}$ was within the optimal temperature range for lamprey reproduction [73]. Animals were randomly assigned to two treatment groups (6/group): water from a tank (pheromone source tank) containing 5 mature males (spermiating male washings, SMW) or 5 immature males (prespermiating male washings, PSMW). Every two days, animals were checked for spermiation. The number of days to reach spermiation was recorded. The same experiment was repeated using 12 immature females (checking for egg release), and data were analyzed with the $\chi^{2}$ test.

\section{Pheromone exposure experiment 2}

Two hundred and fifty-two immature females and males were acclimated as described in experiment 1 , and assigned 


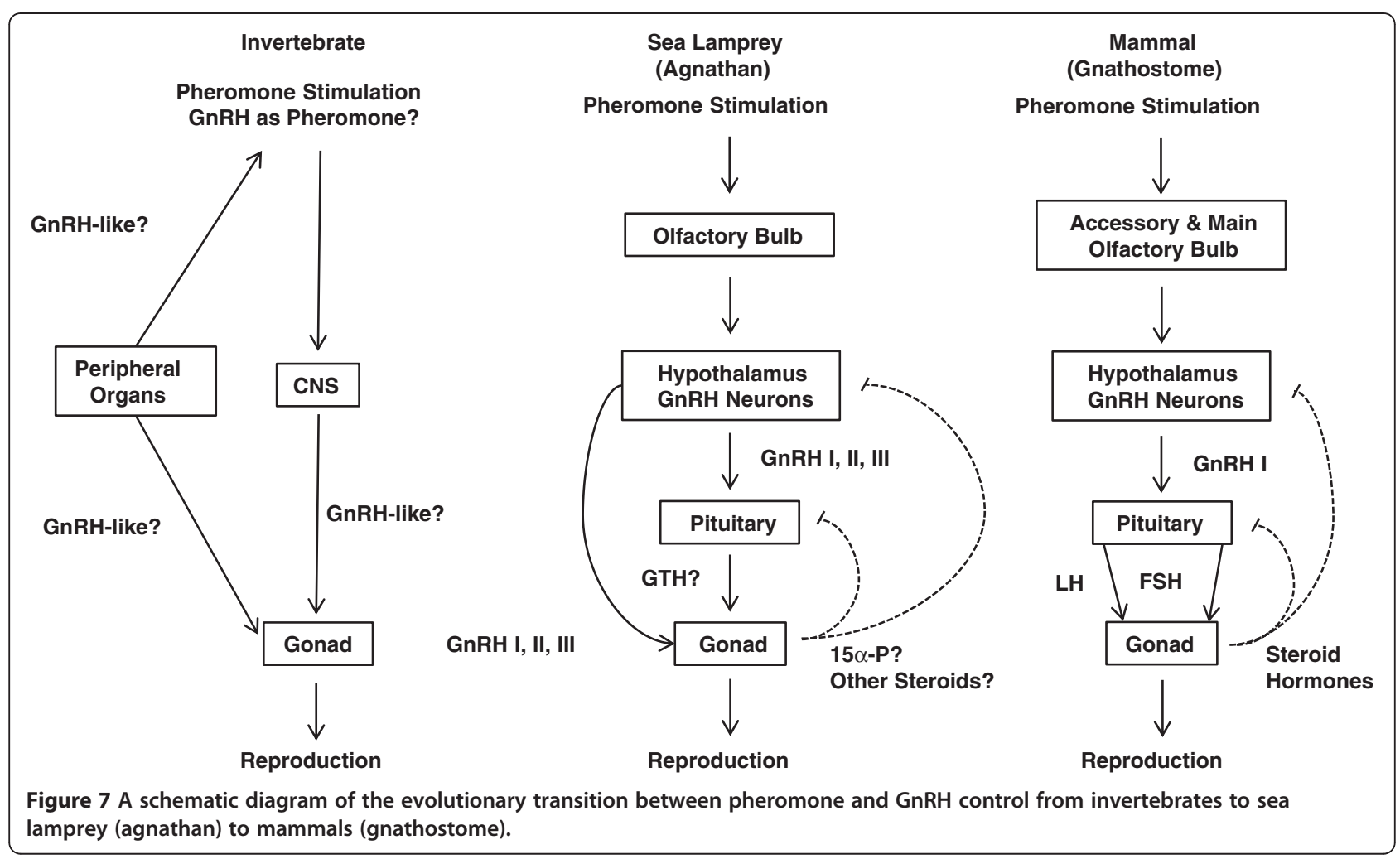

to two treatment groups (control or SMW). At $0 \mathrm{~h}$ (immediately before introducing the odorants) and $24 \mathrm{~h}$ (completion of odorant treatment), $1 \mathrm{ml}$ of blood was drawn to obtain plasma according to previously established protocols and stored at $-80^{\circ} \mathrm{C}$ until use [71,72]. Plasma samples were assayed for immunoreactive $15 \alpha-\mathrm{P}$ using HPLC and radioimmunoassays [71,72]. The same experiment was repeated in the summers of 2001, 2002 and 2003. Data were pooled for each month (May, June and July) and analyzed by One-way ANOVA for repeated measurements (before and after pheromone exposures). If treatment effects were detected $(\mathrm{p}<0.05)$, Fisher's PLSD post hoc tests were followed to determine which treatment induced apparent changes in the parameters measured.

\section{Pheromone exposure experiment 3}

To examine the time course of hormonal responses of immature sea lamprey exposed to $3 \mathrm{kPZS}$ at a wide range of concentrations, 108 immature males were acclimated for 2 days (6/tank; test tank: $200 \mathrm{~L}, 16^{\circ} \mathrm{C}$, water replenishment $\left.1 \mathrm{~L} \mathrm{~min}^{-1}\right)$. Each tank was randomly assigned a treatment of $10^{-11} \mathrm{M}, 10^{-10} \mathrm{M}$ or $10^{-9} \mathrm{M} 3 \mathrm{kPZS}$. Immediately before and after pheromone exposure, $1 \mathrm{ml}$ blood was drawn for plasma $15 \alpha-P$ analyses [71,72]. One-way ANOVA was used to compare the changes in plasma $15 \alpha-\mathrm{P}$ concentration $[\Delta 15 \alpha-\mathrm{P}=$ (post-treatment $15 \alpha-\mathrm{P}$ level) - (pre-treatment $15 \alpha-\mathrm{P}$ level)] among groups treated with the same pheromone concentration but sampled at different time points.
Fisher's PLSD post hoc tests were performed if the ANOVA showed significant effects $(\mathrm{p}<0.05)$.

At 0 (control), 2, 4, 8, 24 and $48 \mathrm{~h}$ after pheromone exposure, animals were euthanized with $0.5 \%$ MS222 (Sigma, St. Louis, MO). Eight brain samples were snap frozen and analyzed for transcripts of 1GnRH-I (GAP49, GAP50, and GAP58) [74] and -III, jun, JNK, and 40S ribosomal RNA. Six brain samples from each group were fixed in $4 \%$ paraformaldehyde (in $0.1 \mathrm{M}$ phosphate buffer, pH 7.4) for immunocytochemistry (ICC) and in situ hybridization (ISH) analyses. From each preserved brain, serial transverse sections of $20 \mu \mathrm{m}$ were collected. Neighboring sections were processed for IGnRH-I or -III ICC [53], or lGnRH mRNA ISH. Negative controls (deprived of primary antibody for ICC or using sense probe for ISH) were processed simultaneously in each experiment. ISH and ICC results were examined by investigators with no knowledge of the experimental condition. The number of immunoreactive cells in the preoptic-hypothalamic area was counted [53], and the average number in a square area $\left(0.0625 \mathrm{~mm}^{2}\right)$ was used for statistical analyses. Brain nuclei were identified according to sea lamprey brain atlas by Nieuwenhuys and Nicholson [75]. The nonparametric Kruskal-Wallis test was used to compare the number of IGnRH-I or -III immunoreactive neurons among treatment groups. Parallel experiments were conducted with immature females. 


\section{Pheromone exposure experiment 4}

Since $3 \mathrm{kPZS}$ had no dramatic effects in immature females and the gene expression changed after $2 \mathrm{~h}$ exposure, we only examined the time course of GnRH release in immature males exposed to vehicle (5 ppm methanol) or $10^{-10}$ M 3kPZS. 64 immature males were acclimated as described above. Immediately and at $15 \mathrm{~min}, 30 \mathrm{~min}, 1 \mathrm{~h}$ or $2 \mathrm{~h}$ after pheromone exposure, animals were euthanized and blood was drawn by cardiac puncture for plasma lGnRH-I and III analyses using UPLC-MS/MS (method described below). Brain samples were snap-frozen and analyzed for lGnRH-I and -III using ultra performance liquid chromatography coupled with tandem mass spectrometry (UPLC-MS/MS).

In situ Hybridization used digoxigenin-labeled antisense and sense RNA probes generated by in vitro Transcription Systems (Promega BioSciences, San Luis Obispo, CA, USA). Sections were treated with proteinase $\mathrm{K}$ at room temperature (R.T.) for $10 \mathrm{~min}$ followed by $4 \%$ paraformaldehyde (0.1 M phosphate buffer, $\mathrm{pH}$ 7.4) for $15 \mathrm{~min}$. Sections were incu- bated in prehybridization solution [ $50 \%$ formamide, hybridization salt $(150 \mathrm{mM} \mathrm{NaCl}$, $50 \mathrm{mM}$ EDTA, $50 \mathrm{mM}$ PIPES), Denhardt's solution (Sigma, St. Louis, MO, USA), $2.5 \mu \mathrm{g} / \mathrm{ml}$ calf thymus DNA, $2.5 \mu \mathrm{g} / \mathrm{ml}$ poly-adenosine, $0.2 \%$ sodium dodecyl sulfate (SDS), and $0.1 \%$ diethylpyrocarbonate] at $42^{\circ} \mathrm{C}$ for $2 \mathrm{~h}$, and then in antisense or sense RNA probe in hybridization solution (prehybridization solution with 5\% dextran sulfate) at $60^{\circ} \mathrm{C}$ overnight (about $18 \mathrm{~h}$ ). Sections were rinsed with $4 \times \mathrm{SSC}(150 \mathrm{mM} \mathrm{NaCl}$ and $15 \mathrm{mM}$ sodium citrate), followed by $2 \times$ SSC (with $0.3 \%$ Tween-20) at $68^{\circ} \mathrm{C}$ for 15 min 3 times, $0.2 \times$ SSC (with $0.3 \%$ Tween-20) at $68^{\circ} \mathrm{C}$ for 15 min 3 times, $0.1 \times$ SSC (with $0.3 \%$ Tween-20) at R.T. for $15 \mathrm{~min}$, and then $0.1 \mathrm{M}$ phosphate buffer saline (PBS, pH 7.4). Sections were incubated in alkaline phosphatase-conjugated sheep-anti-digoxigenin Fab fragments (1:1000; Roche Applied Science, Indianapolis, IN, USA) with normal sheep serum (in 0.1 M PBS with $0.3 \%$ Tween-20) at $5^{\circ} \mathrm{C}$ overnight (about $18 \mathrm{~h}$ ). Sections were rinsed in $0.1 \mathrm{M}$ Tris buffer saline (TBS, $\mathrm{pH}$ 9.5) for 15 min 3 times, followed by nitroblue tetrazolium chloride and 5-bromo-4-chloro-3 indolyl phosphate substrate (Roche) for $1 \mathrm{~h}$, rinsed in PBS (pH 7.4) for 15 min 3 times, counter stained with Nuclear Fast Red (Vector Laboratories, Inc., Burlingame, CA, USA) for $5 \mathrm{~min}$, and coverslipped with Vector $A Q$ mounting media.

Real time quantitative RTQ-PCR followed the procedure described by Chung-Davidson et al. [53]. Synthetic oligos were used as standards and run on the sample plate. 40S ribosomal RNA was used as an internal standard and confirmed to have no change in the expression level in all experiments. RTQ-PCR data (among groups treated with same pheromone concentration but sampled at different time points) were analyzed by one-way ANOVA followed by Fisher's PLSD post hoc tests if the ANOVA showed significant time effects $(\mathrm{p}<0.05)$. The sequence for primers and TaqMan RGB probe (Applied Biosystems) for each mRNA was listed below. 40S ribosomal RNA: 5' primer (5'ACCTA CGCAGGAACAGCTATGAC3'), probe (5'ATCTCGAG CAGCTGAA3'), 3' primer (5'CGACGAATTCCACCAC ATTG3'). Jun: 5' primer (5'CATGGCCGCAAACTTTG G3'), probe (5'CACGAACCTGACCAGC3'), 3' primer (5'CCACCTCCCTGCTGATGCT3'). JNK: 5 ' primer (5'T CAGGCGTGTGGCCAAGT3'), probe (5'CCATGACTT GATCGAATGT3'), 3' primer (5'GAATCAAATTGAGA ACGCAAACG3'). Lamprey GnRH-III: 5' primer (5'TGA CACGAACCCTGTCAATGA3'), probe (5'ATGCCCTC GCTGTGGT3'), 3' primer (5'ACAAAGGGTCTAAGA GACGTCACA3'). To analyze three transcripts of lGn RH-I, we used the same 5' primer (5'TGAATTACGCG CAGCACTACTC3') and probe (5'TGGAATGGAAACC CGG3'), but the 3 ' primers were designed so that they were located at the splice junction of each corresponding transcript (GAP49: 5'CTCCTCCAGGTCTCGTTTGC3'; GAP50: 5'CTCCTGCTCCAGGTCTCGTT3'; GAP58: 5'C CAGCTCTCGTGTGTGACTGA3').

\section{UPLC-MS/MS analyses of IGnRH}

lGnRH-I standard was custom synthesized from GenScript USA Inc. (Piscataway, NJ, USA). IGnRH-III and LHRH were purchased from BAChem Americas, Inc. (Torrance, CA, USA). Each compound was dissolved in 50\% metha$\mathrm{nol} / \mathrm{H}_{2} \mathrm{O}(\mathrm{v} / \mathrm{v})$ to make $1 \mathrm{mg} / \mathrm{ml}$ stock solution, and stored at $-20^{\circ} \mathrm{C}$ until use. Subsequent dilutions were made in $50 \%$ methanol/ $/ \mathrm{H}_{2} \mathrm{O}$. Calibration standard spiking solutions were prepared in a range from 0.01 to $10 \mathrm{ng} / \mathrm{ml}$ by spiking appropriate stock solutions to brain tissue or plasma extracts. Internal standard (LHRH) solution $(50 \mathrm{ng} / \mathrm{ml})$ was prepared in $50 \%$ methanol/ $/ \mathrm{H}_{2} \mathrm{O}$ and $20 \mu \mathrm{l}$ was added to each sample (1 ng per sample).

Brain samples were weighed and homogenized with $400 \mu \mathrm{l}$ of $1 \%$ formic acid in cold $\left(-20^{\circ} \mathrm{C}\right)$ acetonitrile with $1 \mathrm{ng}$ internal standard. $1 \mathrm{ml}$ of $1 \%$ formic acid in cold $\left(-20^{\circ} \mathrm{C}\right)$ acetonitrile was added to the homogenate, incubated at $-20^{\circ} \mathrm{C}$ for $15 \mathrm{~min}$, and centrifuged at $15,800 \times \mathrm{g}$ for $20 \mathrm{~min}$ at $4^{\circ} \mathrm{C}$. The supernatant was transferred to a new tube, freeze-dried using a CentriVap Cold Trap Concentrator (Labconco Co., Kansas City, MO, USA), and reconstituted in $1 \mathrm{ml}$ water solution with $3 \%$ acetic acid and 1\% TFA. $500 \mu \mathrm{l}$ plasma samples were processed in a similar procedure without the homogenization step. The reconstituted supernatant was transferred to a SPE HLB cartridge preconditioned with $3 \mathrm{ml}$ methanol followed by $3 \mathrm{ml}$ loading solution (water/ acetic acid/TFA, 96:3:1, v/v), washed with $3 \mathrm{ml}$ loading solution and followed by $3 \mathrm{ml}$ loading solution/methanol 
(70:30, v/v). Samples were eluted with $3 \mathrm{ml} \mathrm{3 \%}$ acetic acid/ solution: methanol (30:70, v/v), freeze-dried and reconstituted in $100 \mu \mathrm{l} 3 \%$ acetic acid/methanol (50:50, $\mathrm{v} / \mathrm{v}$ ), vortexed for 30 seconds and transferred to glass autosampler vials for UPLC-MS/MS analyses.

A Waters Xevo TQ-S mass spectrometry was coupled to an H-Class UPLC system with a Waters BEH C18 column $(1.0 \times 50 \mathrm{~mm}, 1.7 \mu \mathrm{m}$ particle size $)$ and oven temperature at $35^{\circ} \mathrm{C}$. The injection volume was $10 \mu \mathrm{l}$, and the UPLC flow rate is $0.15 \mathrm{ml} / \mathrm{min}$ with a gradient (mobile phase A: $0.1 \%$ formic acid in water; $\mathrm{B}: 0.1 \%$ formic acid in acentonitrile): initial, $88 \% \mathrm{~A}$ and $12 \% \mathrm{~B} ; 0.5 \min 88 \% \mathrm{~A}$, $4 \min 65 \%$ A, $7 \min 1 \%$ A, $8 \min 1 \%$ A, $8 \min 88 \%$ A, and $9 \min 88 \%$ A. Mass spectra were acquired using electrospray ionization in positive ion mode and MRM. The capillary voltage, cone voltage, and $\mathrm{rf}$ lens setting were $3.20 \mathrm{kV}, 64 \mathrm{~V}$, and 0.3 , respectively. The flow rates of cone gas and desolvation gas were 20 and $400 \mathrm{~L} / \mathrm{h}$, respectively. The source temperature and desolvation temperature were 150 and $500^{\circ} \mathrm{C}$. Collision-induced dissociation employed argon as collision gas at a manifold pressure of $2 \times 10^{-3} \mathrm{mbar}$, and collision energies and source cone potentials were optimized for each transition using Waters QuanOptimize software. Data were acquired with MassLynx 4.1 and QuanLynx softwares.

\section{Additional file}

Additional file 1: Figure 1. 3kPZS exposure had no effect on hindbrain IGnRH-I concentrations in immature male sea lamprey. Data are presented as mean \pm S.E.M. Figure 2. $3 \mathrm{kPZS}$ exposure had no effect on hindbrain IGnRH-III concentrations in immature male sea lamprey. Data are presented as mean \pm S.E.M. Figure 3. 3kPZS exposure did not change the number of lamprey (I) GnRH-positive neurons in the hypothalamus. Lamprey (I) GnRH in situ hybridization (ISH) showed positive cells (blue stain) in the preoptic area of immature female and male sea lamprey. $20 \mu \mathrm{m}$ Transverse sections were counterstained with nuclear fast red (pink stain). Scale bar: $20 \mu \mathrm{m}$. $3 \mathrm{~V}$ : third ventricle. Figure 4. 3kPZS exposure did not change the number of lamprey (I) GnRH-limmunoreactive neurons in the hypothalamus. IGnRH-I -immunoreactive neurons (red stain) are located in the preoptic area of immature female and male sea lamprey. $20 \mu \mathrm{m}$ transverse sections were counterstained with hematoxylin (blue/purple stain). Scale bar: $50 \mu \mathrm{m}$. $3 \mathrm{~V}$ : third ventricle. Figure 5. $3 \mathrm{kPZS}$ exposure did not change the number of lamprey (I) GnRH-Illimmunoreactive neurons in the hypothalamus. IGnRH-III -immunoreactive neurons (red stain) are located in the preoptic area of immature female and male sea lamprey. $20 \mu \mathrm{m}$ transverse sections were counterstained with hematoxylin (blue/purple stain). Scale bar: $50 \mu \mathrm{m}$. $3 \mathrm{~V}$ : third ventricle.

\footnotetext{
Abbreviations

HPG: Hypothalamic-pituitary-gonadal; GnRH: Gonadotropin-releasing hormone; 3kPZS: 3-keto petromyzonol sulfate; 15a-P: 15a-

hydroxyprogesterone; IGnRH-I: lamprey GnRH-I; IGnRH-III: lamprey GnRH-III; JNK: Jun N-terminal kinase; LH: Luteinizing hormone; GTH: Gonadotropin; SMW: Spermiating male washing; PSMW: Prespermiating male washing; LHRH: Luteinizing hormone-releasing hormone; FSH: Follicle-stimulating hormone; ICC: Immunocytochemistry; ISH: In situ hybridization; RTQPCR: Real-time quantitative PCR; UPLC-MS/MS: Ultra-performance liquid chromatography coupled with tandem mass spectrometry.
}

\section{Competing interests}

The authors declare that they have no competing interests.

\section{Authors' contributions}

YWCD designed the study, carried out the sample collection and all experimental studies, performed the statistical analyses and wrote the manuscript. H Wang developed UPLC-MS/MS methods and collected data in Pheromone Exposure Experiment 4. MJS participated in Pheromone Exposure Experiment 1 and 2. MBB participated in Pheromone Exposure Experiment 2 and 3. NSJ and H Wu participated in Pheromone Exposure Experiment 3. WL conceived of the study, participated in its design and coordination and helped to write the manuscript. All authors read and approved the final manuscript.

\section{Acknowledgements}

We thank Dr. Stacia A. Sower for her generous gifts of lamprey GnRH antibodies. We thank all summer assistants, especially David Partyka, Joseph Bednark, Christine N. Bedore, and Aaron Smuda, for their help in sample collection. We thank the staff of US Fish and Wild life Service Marquette Biological Station (Marquette, MI) and Department of Fisheries and Ocean Canada Sea Lamprey Control Centre (Sault St. Marie, ON, Canada) for supplying animals and (Contribution 1729) US Geological Survey Great Lakes Science Center Hammond Bay Biological Station (Millersburg, MI) for providing animal housing facility. This study is supported by NSF grant IOB0517491, NIH grant 5R24GM83982 and the Great Lakes Fishery Commission to WL.

\section{Author details}

'Department of Fisheries and Wildlife, Michigan State University, 13 Natural Resources Building, 480 Wilson Road, East Lansing, Ml 48824, USA. ${ }^{2}$ Present address: Great Lakes Fishery Commission, 2100 Commonwealth Blvd., Suite 100, Ann Arbor, MI 48105, USA. ${ }^{3}$ Present address: Energy Biosciences Institute, University of California, 130 Calvin Laboratory, MC 5230, Berkeley, CA 94720, USA. ${ }^{4}$ Present address: Department of Microbiology \& Immunology, School of Medicine, Emory University, Rollins Research Center G214, 201 Dowman Drive, Atlanta, Georgia 30322, USA. ${ }^{5}$ Present address: USGS, Great Lakes Science Center, Hammond Bay Biological Station, 11188 Ray Road, Millersburg, Ml 49759, USA.

Received: 11 September 2012 Accepted: 15 January 2013 Published: 20 January 2013

\section{References}

1. Karlson O, Lüscher M: 'Pheromones': a new term for a class of biologically active substances. Nature 1959, 183:55-56.

2. Brennan PA, Zufall F: Pheromonal communication in vertebrates. Nature 2006, 444:308-315.

3. Rekwot PI, Ogwu D, Oyedipe EO, Sekoni VO: The role of pheromones and biostimulation in animal reproduction. Anim Reprod Sci 2001, 65:157-170.

4. Stowers L, Marton TF: What is a pheromone? Mammalian pheromones reconsidered. Neuron 2005, 46:699-702.

5. Wyatt T: Pheromones and signature mixtures: defining species-wide signals and variable cues for identity in both invertebrates and vertebrates. J Comp Physiol A 2010, 196:685-700.

6. Wysocki CJ, Preti G: Facts, fallacies, fears, and frustrations with human pheromones. Anat Rec Part A 2004, 281A:1201-1211.

7. Motofei IG: A dual physiological character for sexual function: libido and sexual pheromones. J Compil BJUI 2009, 104:1702-1708.

8. Preti G, Wysocki CJ, Barnhart KT, Sondheimer SJ, Leyden JJ: Male axillary extracts contain pheromones that affect pulsatile secretion of luteinizing hormone and mood in women recipients. Biol Reprod 2003, 68:2107-2113.

9. Murata K, Wakabayashi Y, Kitago M, Ohara H, Watanabe H, Tamogami S, Warita Y, Yamagishi K, Ichikawa M, Takeuchi Y, Okamura H, Mori Y: Modulation of gonadotrophin-releasing hormone pulse generator activity by the pheromone in small ruminants. J Neuroendocrinol 2009, 21:346-350

10. Okamura H, Murata K, Sakamoto K, Wakabayashi Y, Ohkura S, Takeuchi Y, Mori Y: Male effect pheromone tickles the gonadotrophin-releasing hormone pulse generator. J Neuroendocrinol 2010, 22:825-832. 
11. Yu KL, Peng C, Peter RE: Changes in brain levels of gonadotropinreleasing hormone and serum levels of gonadotropin and growth hormone in goldfish during spawning. Can J Zool 1989, 69:182-188.

12. Zhang W, Stacey NE: A steroidal pheromone and spawning stimuli act via different neuroendocrine mechanisms to increase gonadotropin and milt volume in male goldfish Carassius auratus. Gen Comp Endocrinol 1997, 105:228-238.

13. Sower SA: The endocrinology of reproduction in lampreys and applications for lamprey sterilization. J Great Lakes Res 2003, 29:50-65.

14. Li W, Scott AP, Siefkes MJ, Yan HG, Liu Q, Yun SS, Gage DA: Bile acid secreted by mate sea lamprey that acts as a sex pheromone. Science 2002, 296:138-141.

15. Li K, Siefkes MJ, Brant CO, Li W: Isolation and identification of petromyzesterosterol, a polyhydroxysteroid from sexually mature male sea lamprey (Petromyzon marinus L.). Steroids 2012, 77:806-810.

16. Sorensen PW, Fine JM, Dvornikovs V, Jeffrey CS, Shao F, Wang J, Vrieze LA, Anderson KR, Hoye TR: Mixture of new sulfated steroids functions as a migratory pheromone in the sea lamprey. Nat Chem Biol 2005, 1:324-328.

17. Yun SS, Scott AP, Li W: Pheromones of the male sea lamprey, Petromyzon marinus L.: structural studies on a new compound, 3-keto allocholic acid, and 3-keto petromyzonol sulfate. Steroids 2003, 68:297-304

18. Hardisty MW: The significance of lampreys for biological research. Endeavour 1983, 7:110-115

19. Kuratani S, Kuraku S, Murakami Y: Lamprey as an evo-devo model: lessons from comparative embryology and molecular phylogenetics. Genesis 2002, 34:175-183.

20. Applegate VC: Natural history of the sea lamprey (Petromyzon marinus) in Michigan. In US Fish and Wildlife Service Special Science Report on Fishery Service 1950, 55:237.

21. Hardisty MW, Potter IC: The general biology of adult lampreys. In The biology of lampreys. Volume 1. Edited by Hardisty MW, Potter IC. New York: Academic Press; 1971:127-206.

22. Youson $\mathrm{JH}$, Potter IC: A description of the stages in the metamorphosis of the anadromous sea lamprey, Petromyzon marinus L. Can J Zool 1979, 57:1808-1817

23. Potter IC, Gill HS: Adaptive radiation of lampreys. J Great Lakes Res 2003, 29(Suppl 1):95-112.

24. Siefkes MJ, Scott AP, Zielinski B, Yun S-S, Li W: Male sea lampreys, Petromyzon marinus L., excrete a sex pheromone from gill epithelia. Biol Reprod 2003, 69:125-132

25. Siefkes MJ, Li W: Electrophysiological evidence for detection and discrimination of pheromonal bile acids by the olfactory epithelium of female sea lampreys (Petromyzon marinus). J Comp Physiol A 2004, 190:193-199.

26. Johnson NS, Yun S-S, Thompson HT, Brant CO, Li W: A synthesized pheromone induces upstream movement in female sea lamprey and summons them into traps. PNAS 2009, 106:1021-1026.

27. Li W, Scott AP, Siefkes MJ, Yun SS, Zielinski BS: A male pheromone in the sea lamprey (Petromyzon marinus): an overview. Fish Physiol Biochem 2003, 28:259-262.

28. Siefkes MJ, Winterstein SR, Li W: Evidence that 3-keto petromyzonol sulphate specifically attracts ovulating female sea lamprey, Petromyzon marinus. Anim Behav 2005, 70:1037-1045.

29. Reed KL, Macintyre JK, Tobet SA, Trudeau VL, MacEachern L, Rubin BS, Sower SA: The spatial relationship of $\gamma$-aminobutyric acid (GABA) neurons and gonadotropin-releasing hormone (GnRH) Neurons in larval and adult sea lamprey, Petromyzon marinus. Brain Behav Evol 2002, 60:1-12.

30. Nozaki M, Ominato K, Gorbman A, Sower SA: The distribution of lamprey $\mathrm{GnRH}-\mathrm{III}$ in brains of adult sea lampreys (Petromyzon marinus). Gen Comp Endocrinol 2000, 118:57-67.

31. Sørensen PW, Scott AP: The evolution of hormonal sex pheromones in teleost fish: poor correlation between the pattern of steroid release by goldfish and olfactory sensitivity suggests that these cues evolved as a result of chemical spying rather than signal specialization. Acta Physiol Scand 1994, 152:191-205.

32. Koyama S: Primer: effects by conspecific odors in house mice: a new perspective in the study of primer effects on reproductive activities. Horm Behav 2004, 46:303-310.

33. Misgeld U, Zeilhofer HU, Swandulla D: Synaptic modulation of oscillatory activity of hypothalamic neuronal networks in vitro. Cell Mol Neurobiol 1998, 18:29-43.
34. Caraty A, Evans NP, Fabre-Nys CJ, Karsch FJ: The preovulatory gonadotropin-releasing hormone surge: a neuroendocrine signal for ovulation. J Reprod Fertil Supp/ 1995, 49:245-255.

35. Christian CA, Moenter SM: Critical roles for fast synaptic transmission in mediating estradiol negative and positive feedback in the neural control of ovulation. Endocrinol 2008, 149:5500-5508.

36. Ping L, Mahesh VB, Bhat GK, Brann DW: Regulation of gonadotropinreleasing hormone and luteinizing hormone secretion by AMPA receptors. Evidence for a physiological role of AMPA receptors in the steroid-induced luteinizing hormone surge. Neuroendocrinol 1997, 66:246-253.

37. Lee WS, Smith MS, Hoffman GE: Luteinizing hormone-releasing hormone neurons express Fos protein during proestrous surge of luteinizing hormone. PNAS 1990, 87:5163-5167.

38. Lee WS, Abbud R, Smith MS, Hoffman GE: LHRH neurons express c-Jun protein during proestrous surge of luteinizing hormone. Endocrinol 1992, 130:3101-3103.

39. Park OK, Gugneja S, Mayo KE: Gonadotropin-releasing hormone gene expression during the rat estrous cycle: effect of pentobarbital and ovarian steroids. Endocrinol 1990, 127:365-372.

40. Zoeller RT, Young WS: Changes in cellular levels of messenger ribonucleic acid encoding gonadotropin-releasing hormone in the anterior hypothalamus of female rats during the estrous cycle. Endocrino/ 1988, 123:1688-1689.

41. Gore AC, Roberts JL: Regulation of gonadotropin-releasing hormone gene expression in the rat during the luteinizing hormone surge. Endocrinol 1995, 136:889-896.

42. King JC, Sower SA, Anthony EL: Neuronal systems immunoreactive with antiserum to lamprey gonadotropin-releasing hormone in the brain of Petromyzon marinus. Cell Tissue Res 1988, 253:1-8.

43. Zohar Y, Muñoz-Cueto JA, Elizur A, Kah O: Neuroendocrinology of reproduction in teleost fish. Gen Comp Endocrinol 2010, 165:438-455

44. Sower SA, Moriyama S, Kasaraha M, Takahashi A, Nozaki M, Uchida K, Dahlstrom JM, Kawauchi H: Identification of sea lamprey GTH $\beta$-like CDNA and its evolutionary implications. Gen Comp Endocrinol 2006, 148:22-32.

45. Sower SA: Gonadotropin-releasing hormone in primitive fishes. Prog Clin Biol Res 1990, 342:73-78.

46. Sower SA: Neuroendocrine control of reproduction in lampreys. Fish Physiol Biochem 1990, 8:365-374.

47. Deragon $\mathrm{KL}$, Sower SA: Effects of lamprey gonadotropin-releasing hormone-III on steroidogenesis and spermiation in male sea lampreys. Gen Comp Endocrinol 1994, 95:363-367.

48. Gazourian L, Derragon KL, Chase CF, Pati D, Habibi HR, Sower SA: Characteristics of $\mathrm{GnRH}$ binding in the gonads and effects of lamprey $\mathrm{GnRH}-\mathrm{I}$ and -III on reproduction in the adult sea lamprey. Gen Comp Endocrinol 1997, 108:327-339.

49. Sower SA, Chiang YC, Lovas S, Conlon JM: Primary structure and biological activity of a third gonadotropin-releasing hormone from lamprey brain. Endocrinol 1993, 132:1125-1131.

50. Tobet SA, Nozaki M, Youson JH, Sower SA: Distribution of lamprey gonadotropin releasing hormone-III (GnRH-III) in brains in larval lampreys (Petromyzon marinus). Cell Tissue Res 1995, 279:261-267.

51. Wright GM, McBurney KM, Youson JH, Sower SA: Distribution of lamprey gonadotropin-releasing hormone in the brain and pituitary of larval, metamorphic and adult sea lamprey, Petromyzon marinus. Can J Zool 1994, 72:48-53.

52. Sower SA, Kawauchi H: Update: brain and pituitary hormones of lampreys. Comp Biochem Physiol 2001, 129:291-302.

53. Chung-Davidson Y-W, Bryan MB, Teeter J, Bedore CN, Li W: Neuroendocrine and behavioral responses to weak electric fields in adult sea lampreys (Petromyzon marinus). Horm Behav 2008, 54:34-40

54. Dellovade T, Schwanzel-Fukuda M, Gordan J, Pfaff D: Aspects of GnRH neurobiology conserved across vertebrate forms. Gen Comp Endocrinol 1998, 112:276-282.

55. Stern K, McClintock MK: Regulation of ovulation by human pheromones. Nature 1998, 392:177-179.

56. Burger LL, Haisenleder DJ, Dalkin AC, Marshall JC: Regulation of gonadotropin subunit gene transcription. J Mol Endocrinol 2004, 33:559-584.

57. Bonfil D, Chuderland D, Kraus S, Shahbazian D, Friedberg I, Seger R, Naor Z Extracellular signal-regulated kinase, Jun N-terminal kinase, p38, and cSrc are involved in gonadotropin-releasing hormone-stimulated activity 
of the glycoprotein hormone follicle-stimulating hormone $\beta$-subunit promoter. Endocrinol 2004, 145:2228-2244.

58. Burger LL, Haisenleder DJ, Aylor KW, Marshall JC: Regulation of Lhb and Egr1 gene expression by GnRH pulses in rat pituitaries is both c-Jun Nterminal kinase (JNK)- and extracellular signal-regulated kinase (ERK)dependent. Biol Reprod 2009, 81:1206-1215.

59. Haisenleder DJ, Burger LL, Walsh HE, Stevens J, Aylor KW, Shupnik MA, Marshall JC: Pulsatile gonadotropin-releasing hormone stimulation of gonadotropin subunit transcription in rat pituitaries: evidence for the involvement of Jun $\mathrm{N}$-terminal kinase but not p38. Endocrinol 2008, 149:139-145.

60. Harris D, Bonfil D, Chuderland D, Kraus S, Seger R, Naor Z: Activation of MAPK cascades by GnRH: ERK and Jun N-terminal kinase are involved in basal and GnRH-stimulated activity of the glycoprotein hormone LHßsubunit promoter. Endocrinol 2002, 143:1018-1025.

61. Yokoi T, Ohmichi M, Tasaka K, Kimura A, Kanda Y, Hayakawa J, Tahara M, Hisamoto K, Kurachi $H$, Murata Y: Activation of the luteinizing hormone $\beta$ promoter by gonadotropin-releasing hormone requires c-Jun $\mathrm{NH}_{2-}$ terminal protein kinase. J Biol Chem 2000, 275:21639-21647.

62. Fahien CM, Sower SA: Relationship between brain gonadotropin-releasing hormone and final reproductive period of the adult male sea lamprey, Petromyzon marinus. Gen Comp Endocrinol 1990, 80:427-437.

63. Millar RP, King JA: Structure and functional evolution of gonadotropinreleasing hormone. Int Rev Cytol 1987, 106:149-182.

64. Nozaki M, Gorbman A, Sower SA: Diffusion between the neurophysis and the adenohypophysis of lampreys, Petromyzon marinus. Gen Comp Endocrinol 1994, 96:385-391.

65. Sower SA, Balz E, Aquilina-Beck A, Kavanaugh SI: Seasonal changes of brain $\mathrm{GnRH}-\mathrm{I},-\mathrm{II}$, and -III during the final reproductive period in adult male and female sea lamprey. Gen Comp Endocrinol 2011, 170:276-282.

66. Gazourian L, Evans EL, Hanson L, Chase CF, Sower SA: The effects of lamprey GnRH-I, -III and analogs on steroidogenesis in the sea lamprey (Petromyzon marinus). Aquaculture 2000, 188:147-165.

67. Bolduc TG, Sower SA: Changes in brain gonadotropin-releasing hormone, plasma estradiol 17-beta, and progesterone during the final reproductive cycle of the female sea lamprey, Petromyzon marinus. J Exp Zool 1992, 264:55-63.

68. Kavanaugh SI, Nozaki M, Sower SA: Origins of gonadotropin-releasing hormone $(\mathrm{GnRH})$ in vertebrates: identification of a novel $\mathrm{GnRH}$ in a basal vertebrate, the sea lamprey. Endocriol 2008, 149:3860-3869.

69. Zhang L, Tello JA, Zhang W, Tsai P-S: Molecular cloning, expression pattern, and immunocytochemical localization of a gonadotropinreleasing hormone-like molecule in the gastropod mollusk, Aplysia californica. Gen Comp Endocrinol 2008, 126:201-209.

70. Gorbman A, Whiteley A, Kavanaugh S: Pheromonal stimulation of spawning release of gametes by gonadotropin releasing hormone in the chiton, Mopalia sp. Gen Comp Endocrinol 2003, 131:62-65.

71. Bryan MB, Scott AP, Cerny I, Young BA, Li W: 15 Alphahydroxyprogesterone in male sea lampreys, Petromyzon marinus $\mathrm{L}$. Steroids 2004, 69:473-481.

72. Bryan MB, Young BA, Close DA, Semeyn J, Robinson TC, Bayer J, Li W: Comparison of synthesis of 15 alpha-hydroxylated steroids in males of four North American lamprey species. Gen Comp Endocrinol 2006, 146:149-156.

73. Hanson LH, Manion PJ: Sterility method of pest-control and its potential role in an integrated sea lamprey (Petromyzon marinus) control program. Can J Fish Aquat Sci 1980, 37:2108-2117.

74. Suzuki K, Gamble RL, Sower SA: Multiple transcripts encoding lamprey gonadotropin-releasing hormone-I precursors. J Mol Endocrinol 2000, 24:365-376.

75. Nieuwenhuys R, Nicholson C: Lampreys, Petromyzontoidea. In The Central Nervous System of Vertebrates. Volume 1. Edited by Nieuwenhuys R, ten Donkelaar HJ, Nicholson C. Heidelberg: Springer-Verlag; 1998:397-495.

doi:10.1186/1471-2202-14-11

Cite this article as: Chung-Davidson et al:: Pheromonal bile acid 3ketopetromyzonol sulfate primes the neuroendocrine system in sea lamprey. BMC Neuroscience 2013 14:11.

\section{Submit your next manuscript to BioMed Central and take full advantage of:}

- Convenient online submission

- Thorough peer review

- No space constraints or color figure charges

- Immediate publication on acceptance

- Inclusion in PubMed, CAS, Scopus and Google Scholar

- Research which is freely available for redistribution

Submit your manuscript at www.biomedcentral.com/submit
C Biomed Central 